University of Nebraska - Lincoln

DigitalCommons@University of Nebraska - Lincoln

$10-9-2006$

Contribution of the NASA Land-Cover/Land-Use Change Program to the Northern Eurasia Earth Science Partnership Initiative: An overview

Garik Gutman

NASA

Follow this and additional works at: https://digitalcommons.unl.edu/nasapub

Part of the Physical Sciences and Mathematics Commons

Gutman, Garik, "Contribution of the NASA Land-Cover/Land-Use Change Program to the Northern Eurasia Earth Science Partnership Initiative: An overview" (2006). NASA Publications. 8.

https://digitalcommons.unl.edu/nasapub/8

This Article is brought to you for free and open access by the National Aeronautics and Space Administration at DigitalCommons@University of Nebraska - Lincoln. It has been accepted for inclusion in NASA Publications by an authorized administrator of DigitalCommons@University of Nebraska - Lincoln. 


\title{
Contribution of the NASA Land-Cover/Land-Use Change Program to the Northern Eurasia Earth Science Partnership Initiative: An overview
}

\author{
Garik Gutman \\ NASA Headquarters, Washington DC, USA
}

Received 27 May 2005; accepted 19 July 2006

Available online 9 October 2006

\begin{abstract}
The Northern Eurasia Earth Science Partnership Initiative (NEESPI) is a rapidly growing program that involves national government agencies, academia and private organizations in the U.S., Europe, Japan and Northern Eurasia. During the last decade the Northern Eurasian region have been undergoing socioeconomic, climatic and demographic changes. The causes of these changes, the associated interactions between the land surface, the atmosphere and the surrounding ocean and the resultant impact on the sustainability of land use of the region are important topics for scientific research. The NEESPI Science Plan has been prepared as an integrated regional study to better understand these hemispheric-scale interactions, to evaluate the combined role of climate and anthropogenic impacts on the Northern Eurasia ecosystems, and to assess how future human actions would affect the global climate and ecosystems of the region. Projections of the consequence of global changes on the regional environment, the economy and the quality of life in Northern Eurasia that is of primary importance to the nations in the region is an additional focus of this initiative. The NASA Land-Cover/Land-Use Change (LCLUC) Program has supported NEESPI since its inception, and currently funds 26 NEESPI projects. Several other NASA programs are also currently supporting or planning to support the NEESPI. The NEESPI program links to the major international programs under the Earth System Science Partnership (IGBP, IHDP, DIVERSITAS and WCRP) and under the Global Terrestrial Observing System, such as the Global Observation of Forest Cover/Global Observation of Landcover Dynamics (GOFC/GOLD). A number of the NEESPI science activities are aligned with the Global Earth System of Systems (GEOSS) objectives, giving an emphasis to societal benefits, so that the NEESPI framework can serve as a regional test bed for international cooperation in developing a system of observational systems. Since it is a new program, most of the NEESPI research projects have just started. Therefore, rather than describing these projects this paper focuses on presenting some results of the longer term projects which are being continued under NEESPI, and on the expected products from the program and its future directions. More information on the projects can be found at http://neespi.org or http://lcluc.hq.nasa.gov.
\end{abstract}

(C) 2006 Elsevier B.V. All rights reserved.

\section{Introduction}

Northern Eurasia - a geographic area, comprising the territory of the former Soviet Union, northern China,

E-mail address: ggutman@nasa.gov. Mongolia, Scandinavia and Eastern Europe - is a study

0921-8181/\$ - see front matter (C) 2006 Elsevier B.V. All rights reserved. doi:10.1016/j.gloplacha.2006.07.017 
area of an international, interagency program NEESPI (Northern Eurasia Earth Science Partnership Initiative, http://neespi.org) (Fig. 1). The National Aeronautics and Space Administration (NASA) is among the NEESPI major partners, with several NASA programs contributing to this initiative. The NASA Land-Cover/Land-Use Change (LCLUC) Program has supported the NEESPI since its inception (Gutman et al., 2004). Northern Eurasia is of special interest for studying LCLUC processes due to (a) the dramatic socio-economic shifts throughout this region during the past decades and (b) the strong land cover-climate interactions that are not yet well understood. The rapid land-use and land-cover changes create a possibility for large and significant biological and climatic regional feedbacks that could be of global importance. Significant changes in land use, coupled with climate change, will likely affect a number of important sectors, such as forestry, agricultural systems and the coastal zone, and may have significant societal impacts. The NEESPI covers a vast area with numerous geo-botanic zones from arctic to forest to steppe and arid. One of the reasons the NEESPI geographic domain is important for global change studies is because about quarter of the world's forests are located in Northern Eurasia. Fires, insect invasions leading to defoliation, and forest exploitation by humans are the major disturbances in these forests. Interactions between these disturbances and climate variability are complex, with consequences for carbon dynamics, which have yet to be well understood. In the non-boreal zone of Northern Eurasia, other aspects of LCLUC, such as changes in water resources and carbon emissions following institutional changes and the shifts in agricultural practice, come into play. The paper describes expected results that should come out in about 2-3 years and the future directions the program is taking.

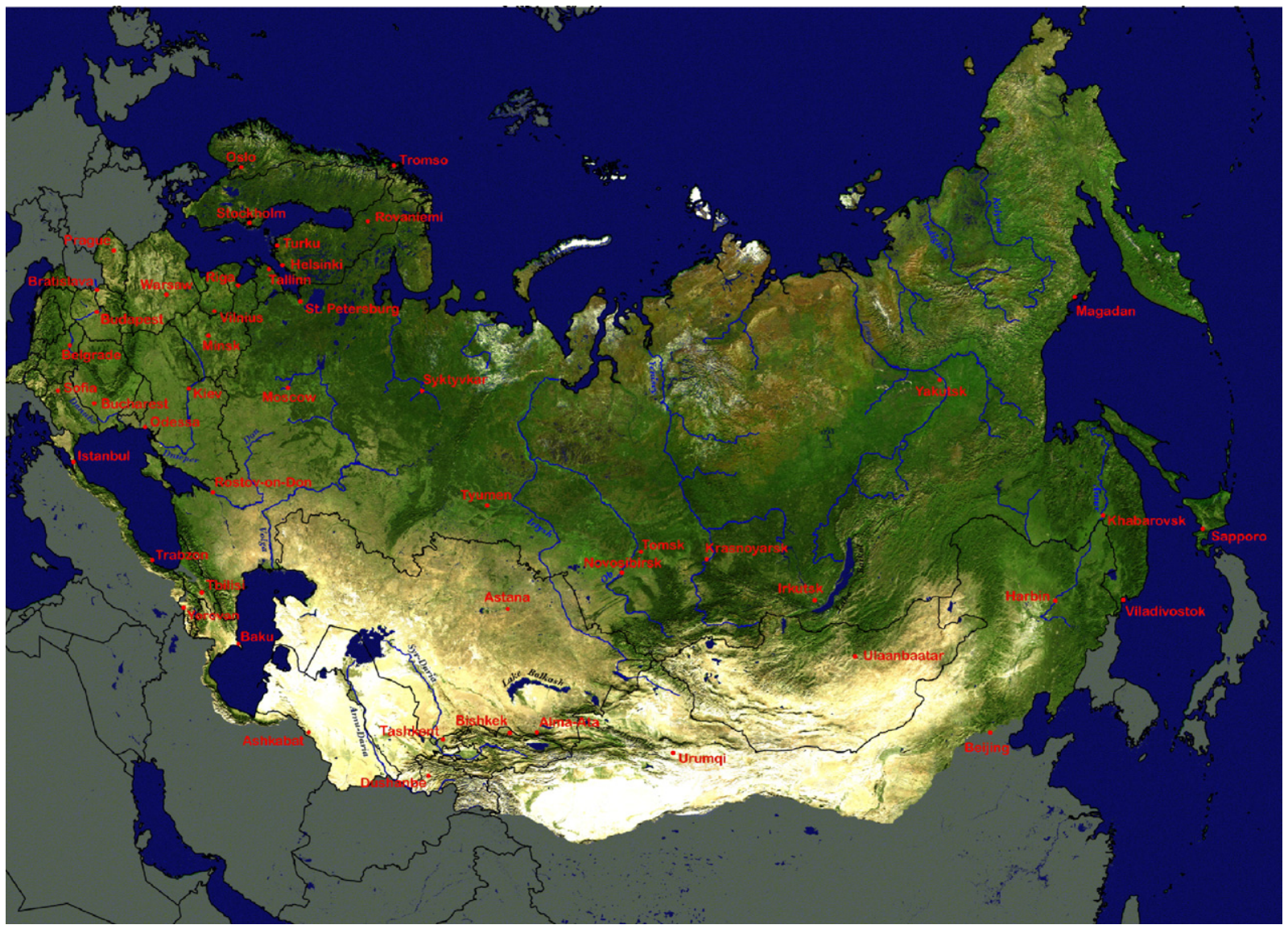

Fig. 1. Northern Eurasia as defined in the NEESPI program. Moderate-resolution imaging spectroradiometer (MODIS) $1 \mathrm{~km}$ true color composite from August 20 to 28, 2004 data. Shaded relief adjustment using the Shuttle Radar Topography Mission (SRTM) GTOPO30 elevation data set compiled by USGS EROS Data Center. Shades of green correspond to vegetated land. Light brown and yellow indicate sparse vegetation and arid areas. Water bodies are shown in blue. Grey areas correspond to land surfaces outside the NEESPI study area. Produced by Dr. Mutlu Ozdogan (NASA GSFC). (For interpretation of the references to colour in this figure legend, the reader is referred to the web version of this article.) 


\section{Background}

After the breakup of the Soviet Union, new opportunities have emerged for U.S. scientists to collaborate with Russian researchers. In mid-1990s the NASA LCLUC Program supported a joint study between Russian and U.S. scientists to evaluate the utility of recently declassified products derived from national security data, for monitoring characteristics of boreal forests (EWG, 1999). The study focused on demonstrating how these derived products could be used in combination with information collected by civilian satellites, such as Landsat, RESURS, and SPOT. This project was conducted under the auspices of the Environmental Working Group created in the summer of 1995 following the so-called Gore-Chernomyrdin agreement on economic and technological cooperation. The use of declassified information was made possible after President Clinton signed an Executive Order, directing the declassification of intelligence imagery acquired by the first generation of photo-reconnaissance satellites, such as a system code-named CORONA. ${ }^{1}$ The results of the joint study demonstrated the utility of the information derived from national security systems and showed that the combined use of archival national security and civil satellite images provided a unique opportunity to assess changes in land-use types and forest cover, analyze qualitative changes in forest structure, and assess changes in forest health attributable to fires, insect outbreaks and forest exploitation. This program initiated an active collaboration between NASA and Russian scientists with an emphasis on forest ecosystems. Building on these collaborations, the LCLUC Program supported a study led by ERIM International and University of Virginia (UVA) on the effects of the development of the Baikal-Amur mainline railroad on patterns of carbon flux in southern Siberia (Kasischke et al., 1999; Shugart et al., 2000; Isaev et al., 2002). Their study confirmed that creation of trans-Siberian railroads have increased human land clearing. It was also concluded that species composition in boreal regions is defined by disturbance regimes (logging, fire, and infestation) and change in these regimes has the capacity to alter productivity and the ability of forests to store carbon, and that land-use trends are clearly linked to socio-economic and political actions. Another project that was conducted in the early years of the LCLUC program was a comparative study on modeling carbon dynamics and their economic implications in two forest regions (Pacific Northwestern

\footnotetext{
${ }^{1}$ Currently, the declassified imagery is available through the U. S. Geological Survey's EROS Data Center.
}

USA and Northwestern Russia) led by the Oregon State University (OSU) with participation of the USDA Forest Service Pacific Northwest Research Station (Krankina et al., 1998, 2004a,b; Healey et al., 2005; Alig et al., in press). The analysis of forest inventory data showed differences in forest structure and composition and the decline and rebound of forest production associated with Russian economic collapse and recovery. As a result of differences in historical land use, the forests in the Pacific Northwest were a source of carbon while the forests in Northwest Russia were identified as a sink. Projections of carbon storage were made for different land-use scenarios. Both the ERIM-UVA and the OSU projects developed active collaborations with Russian forest scientists and remote sensing specialists, that in the future provided a solid base for developing the Northern Eurasian science and information network.

Bergen et al. (2003) gave a comprehensive overview of the Russian forest-related projects, supported by the LCLUC Program in pre-NEESPI years and based largely on the cooperation developed with scientists from the Russian Academy of Sciences, Russian State Forest Inventories, and Russian Federal Forest Service. Bergen et al. described selected results of completed and ongoing research projects grouped under four LCLUC categories: (1) forest dynamics, (2) fire behavior, (3) carbon budgets, and (4) new remote sensing analysis methods. Except for the OSU project, the main collaborating partners in Russia in the forest studies at that time were the Center for Forest Ecology and Productivity in Moscow and the Sukachev Institute of Forest Research in Krasnoyarsk of the Russian Academy of Sciences. Capitalizing on considerable forest inventory data and forest ecology expertise in Russia as well as rapid advances in remote sensing capabilities after the launch of Landsat-7 and Terra satellites, the U.S.Russia joint projects produced a large body of scientific results showcasing the potential of growing databases of multi-decadal imagery accumulated by the Landsat and AVHRR programs. Coupling remote sensing-derived information with models and inventory-derived information on forest age and cutting history significantly enhanced the information content of the remote sensing data. Results of scientific research on disturbance, including fire behavior and the interaction of logging and fire in the Russian boreal forest, have contributed to a greater understanding of the role of Russian forests in the global carbon budget (see Bergen et al., 2003). Additionally, the link between forest dynamics and socio-economic factors in Russia were explored under these projects. It was found that "using models, it is possible to project what the forest in these regions will 
look like in future decades and centuries". Forest gap models showed that the composition of the forest changes significantly after logging and fire and may not return to its original composition for centuries even without additional disturbance (Yan and Shugart, 2005). Additionally, land-cover change detected from remote sensing data during 1975-2000 has confirmed that the composition of the Siberian boreal forest in the areas of study is indeed changing (Bergen et al., 2003; Krankina et al., 2004a,b).

Much effort in the pre-NEESPI projects was directed at studying the major natural disturbance process in boreal systems - forest fires. Analysis of natural and experimental fires contributes to the implementation of remote sensing-based algorithms for their mapping and monitoring. In Russia, fires cover a greater area than any other type of vegetation disturbance. Satellite data reveal a substantial, year-to-year variation in areas burned by wildfire (Soja et al., 2004a,b) that in extreme years far exceed historical estimates by official Russian sources. Results of the NASA projects have shown that "the impact of fires on terrestrial carbon storage in boreal forest regions has been vastly underestimated" (Conard et al., 2002). Moreover, this study noted that "changes in forest and fire management, land-use practices, and regional climate affect fire risk and ecosystem damage from fire in ways that are presently poorly understood". However, during the last several years, remote sensingbased methods for detecting burned areas and fire severity have been substantially improved to provide inputs into global and regional models of carbon cycling and atmospheric chemistry (Ito and Penner, 2004).

Most studies have agreed that the region is a net sink for carbon (e.g., Shvidenko and Nilsson, 1996), but analyses based on atmospheric data, models and forest inventories indicate that a large uncertainty in the carbon budget estimates and in the spatial patterns and temporal dynamics of $\mathrm{CO}_{2}$ fluxes in the region still exists. U.S. scientists collaborated with several Russian organizations to study the carbon budget of forest ecosystems in the St. Petersburg's region of Russia. Their integrated approach involved the use of forest inventory data, ecological studies, data on land-use change, and Landsat imagery (Krankina et al., in press). A recent study by scientists at the Woods Hole Research Center in cooperation with OSU quantified the current distribution of carbon storage in Russia (Houghton et al., in preparation). The new estimates of the total amount of carbon stored in forest vegetation ranged between 23 and $33 \mathrm{Gt} \mathrm{C}$, with average forest biomass between 40 and $44 \mathrm{Mg} \mathrm{C} / \mathrm{ha}$, most of the uncertainty resulting from different definitions/areas of forest.
To summarize, pre-NEESPI results on Siberian forests confirmed the notion that pre-settlement forest (before 1750) had a much greater proportion of dark coniferous (spruce/fir/Siberian pine) than the current forests, which are dominated by pine (Pinus sylvestris) or mixed conifer-deciduous types. The primary drivers of forest dynamics in Siberia today are logging, fires, insects, and agricultural abandonment. In addition, investment in infrastructure for forest and fire management has changed since the collapse of the former Soviet Union. As for the most recent land-use change effects, time-series data show that the changeover from the Soviet Union to emerging market economy has had a significant and observable impact on the landscape of Central Siberia (Krankina et al., 2004a).

Finally, these NASA LCLUC projects fostered growing international collaboration at the individual, institutional, and national government levels. Currently, Russian and U.S. scientists are continuing to work together in the NEESPI framework to further our knowledge on the influence of LCLUC on terrestrial ecosystems of Northern Eurasia. Collaborations with other countries of the NEESPI region have now expanded to include China, Ukraine, Uzbekistan, Kazakhstan, and Mongolia.

\section{The NEESPI program}

The NEESPI program is an evolving program of internationally supported Earth system science research, focusing on issues in Northern Eurasia that are relevant to regional and global scientific and decision-making communities. Until recently, NASA has been the driving force for NEESPI development, relying on the wellestablished relationship between NASA and the Russian Academy of Sciences described above. Currently, the NEESPI involves more than 15 countries and is represented by several U.S. and international agencies and institutions, involving about 300 scientists from over 170 institutions and growing in an accelerate rate. It operates as an integrated regional study, linking to the international science programs within the Earth Science System Partnership, which is an association of the four global science programs: IGBP, IHDP, WCRP and DIVERSITAS. The primary links are currently with six global projects supported by those global programs: the Global Land Project, the Global Carbon Project, the Global Water System Project, the Global Energy and Water Cycle Experiment, the Climate and Cryosphere Project, and the Integrated Land Ecosystem-Atmosphere Processes Study Project (Fig. 2). Ultimately, the goal of NEESPI is to communicate and apply the 


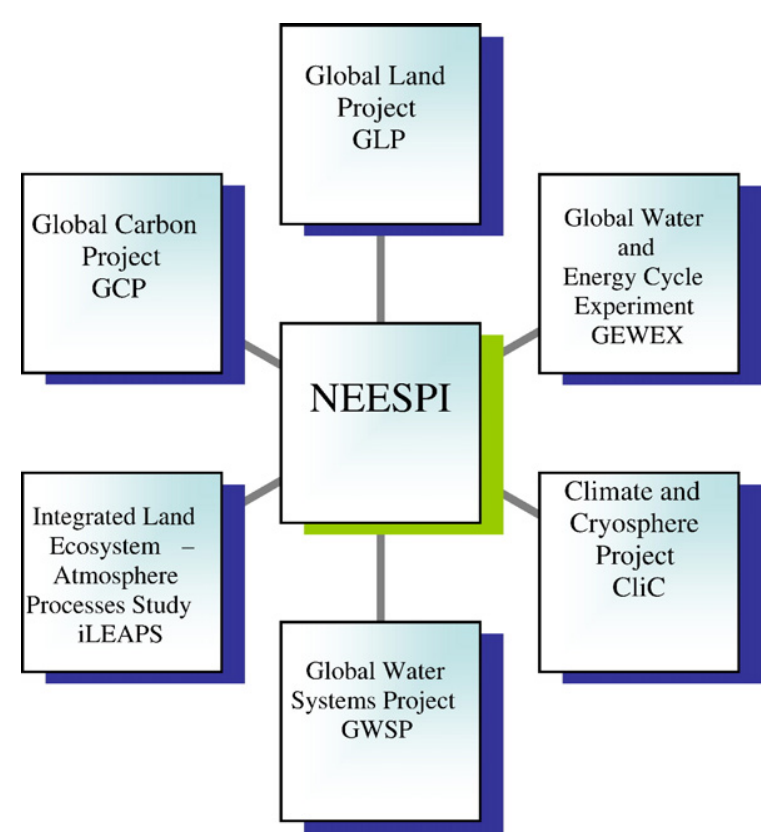

Fig. 2. NEESPI linkages to IGBP/IHDP and WCRP projects.

enhanced knowledge developed for this region to specific societal concerns that face national and international decision-makers of the partnering institutions and countries.

The NEESPI LCLUC projects aim at helping to resolve the following science questions of the NEESPI science plan (see Groisman, this issue):

1. What has been the role of anthropogenic impacts on producing the current status of the Northern Eurasian ecosystems both through local land use/land cover modifications and through global gas and aerosol inputs? What are the hemispheric-scale interactions, and what are the local effects?

2. How will future human actions in this region affect the Northern Eurasia and global ecosystems? How can we describe these processes using a suite of local, regional, and global models?

3. What will be the consequences of global changes for the regional environment, the economy, and the quality of life in Northern Eurasia?

Below is a brief description of the NASA LCLUC components of the NEESPI Program. Details on the NEESPI LCLUC projects could be found at http://cluc. hq.nasa.gov, whereas all the NEESPI projects are described at http://neespi.org. There are currently 26 NASA-supported LCLUC projects, about equally split in two groups, one focusing on the processes in the boreal zone and the other focusing on non-boreal zone of Northern Eurasia (see Table 1). A synthesis of the results will follow at the final stage of the current projects in about 3 years.

\subsection{Boreal zone}

The Russian boreal zone is probably the world's largest carbon pool with about $1 / 2$ of global terrestrial carbon, large amounts of carbon being stored in the soils (including permafrost) and peatlands of this region. To develop a comprehensive regional carbon budget scientists have been examining carbon stocks and their change in live forest biomass, coarse woody debris, peatlands, forest products, and soils.

The impacts of changes in land cover on carbon cycle processes in the boreal zone are studied in several projects, each project focusing on a particular aspect. The projects include modeling the boreal forest-cover dynamics with disturbances like insect outbreaks and climate change effects. A forest simulator has been designed to interface with larger scale biophysically based model components, projecting vegetation change and forest carbon balance under dynamic climate change scenarios (PI: Shugart, University of Virginia); simulating a complete span of carbon dynamics for forest ecosystems utilizing data from a network of $\mathrm{CO}_{2}$ eddy flux towers, with a satellite-driven diagnostic model to estimate forest photosynthesis, in conjunction with a process-oriented biogeochemical model, which quantifies turnover of organic carbon in the forest soil profiles by precisely tracking decomposition, nitrification, denitrification and fermentation (PI: Li, University of New Hampshire); and validating satellite-derived land-cover products in various situations, resulting from ecosystem disturbance due to fire, timber harvest, insect outbreaks, agricultural conversion and abandonment, melting permafrost and forest regrowth (PI: Krankina, Oregon State University). The impact of forest disturbance on forest structure and biomass storage is being assessed with high-resolution satellite data (PI: Ranson, NASA Goddard Space Flight Center). The forests are stratified using coarse-resolution data, mainly the Moderate Resolution Imaging Spectroradiometer (MODIS) products, and relying on local forest inventory maps and other statistical data sets and field samples. The field measurements and forest inventory maps provide ground truth data for mapping forest disturbance and biomass from Landsat ETM+ and SAR data at intensive study sites. These data sets are being used to develop models to convert ICESAT GLAS waveforms to forest stand 
Table 1

\begin{tabular}{|c|c|c|}
\hline Csiszar & $\begin{array}{l}\text { University of } \\
\text { Maryland }\end{array}$ & Biomass burning in Russia \\
\hline Conard & USDA Forest Service & $\begin{array}{l}\text { Wildfire impacts on carbon stocks and exchanges in forests of Central Siberia: Quantifying effects of fire } \\
\text { intensity, fire severity, and burning conditions }\end{array}$ \\
\hline Qi & $\begin{array}{l}\text { Michigan State } \\
\text { University }\end{array}$ & Land use and land cover dynamics of China in support of GOFC/GOLD and NEESPI sciences \\
\hline Sun & UMD/NASA GSFC & $\begin{array}{l}\text { Comparative studies on carbon dynamics in disturbed forest ecosystems: eastern Russia and northeastern } \\
\text { China }\end{array}$ \\
\hline Shugart & University of Virginia & Modeling the carbon dynamics of the Eurasian boreal forest \\
\hline $\mathrm{Li}$ & $\begin{array}{l}\text { University of New } \\
\text { Hampshire }\end{array}$ & $\begin{array}{l}\text { Quantifying } \mathrm{CO}_{2} \text { fluxes from boreal forests in northern Eurasia: an integrated analysis of flux tower data, } \\
\text { remote sensing data and biogeochemical modeling }\end{array}$ \\
\hline Tubiello & Columbia University & Carbon, climate and managed land in Ukraine: integrating data and models of land use for NEESPI \\
\hline Lettenmaier & $\begin{array}{l}\text { University of } \\
\text { Washington }\end{array}$ & $\begin{array}{l}\text { Diagnosis and prognosis of changes in lake and wetland extent on the regional carbon balance of northern } \\
\text { Eurasia }\end{array}$ \\
\hline Ojima & $\begin{array}{l}\text { Colorado State } \\
\text { University }\end{array}$ & Northern Eurasian C-land use climate interaction in the semi-arid regions \\
\hline Woodcock & Boston University & Quantifying the effects of land use change on carbon budgets in the Black Sea region and China \\
\hline Ranson & NASA GSFC & Boreal zone forest type and structure from EOS data sets \\
\hline Aizen & University of Idaho & $\begin{array}{l}\text { Estimation of seasonal snow cover and glacial area changes in central Asia (Tien Shan) during the last } 50 \text { years } \\
\text { using NASA ESE products and in-situ data }\end{array}$ \\
\hline Vorosmarty & $\begin{array}{l}\text { University of New } \\
\text { Hampshire }\end{array}$ & $\begin{array}{l}\text { Role of land use/land cover change in water budget and water use across central Asia: an interactive data } \\
\text { compendium for hydrological analysis }\end{array}$ \\
\hline Chen & $\begin{array}{l}\text { The University of } \\
\text { Toledo }\end{array}$ & Effects of land use change on the energy and water balance of the semi-arid region of Inner Mongolia \\
\hline Henebry & $\begin{array}{l}\text { South Dakota State } \\
\text { University }\end{array}$ & $\begin{array}{l}\text { Evaluating the effects of institutional change on regional hydrometeorology: assessing the vulnerability of the } \\
\text { Eurasian semi-arid grain belt }\end{array}$ \\
\hline Geerken & Yale University & Ecological monitoring in semi-arid central and west Asia: drivers and trajectories \\
\hline Eshleman & $\begin{array}{l}\text { University of } \\
\text { Maryland }\end{array}$ & Exacerbation of flooding responses due to land cover/land use change: a comparative study \\
\hline Imhoff & $\begin{array}{l}\text { Goddard Space Flight } \\
\text { Center }\end{array}$ & $\begin{array}{l}\text { Global distribution of human appropriation of fresh water: an Earth observation-supported strategy linking } \\
\text { biophysics and socio-economics for addressing water vulnerability }\end{array}$ \\
\hline Sokolik & $\begin{array}{l}\text { Georgia Institute of } \\
\text { Technology }\end{array}$ & $\begin{array}{l}\text { Understanding the role of changes in land-use/land-cover and atmospheric dust loading and their coupling on } \\
\text { climate change in the NEESPI study domain drylands }\end{array}$ \\
\hline Soja & NAI/NASA LaRC & Wildfire, ecosystems, and climate in Siberia \\
\hline Vorosmarty & $\begin{array}{l}\text { University of New } \\
\text { Hampshire }\end{array}$ & Role of land cover and land use change in hydrology of Eurasian pan-Arctic \\
\hline Krankina & $\begin{array}{l}\text { Oregon State } \\
\text { University }\end{array}$ & NELDA: monitoring and validating the distribution and change in land cover across northern Eurasia \\
\hline Walker & University of Alaska & $\begin{array}{l}\text { Application of space-based technologies to examine land-cover/land-use change along a transect on the Yamal } \\
\text { Peninsula and Novaya Zemlya, Russia }\end{array}$ \\
\hline Gitelson & $\begin{array}{l}\text { University of } \\
\text { Nebraska }\end{array}$ & $\begin{array}{l}\text { Land cover land use change effects on surface water quality: integrated MODIS and SeaWiFS assessment of } \\
\text { the Dnieper and Don River basins and their reservoirs }\end{array}$ \\
\hline Radeloff & $\begin{array}{l}\text { University of } \\
\text { Wisconsin }\end{array}$ & $\begin{array}{l}\text { Post-USSR land cover change in Eastern Europe: socioeconomic forcings, effects on biodiversity, and future } \\
\text { scenarios }\end{array}$ \\
\hline Loboda & $\begin{array}{l}\text { University of } \\
\text { Maryland }\end{array}$ & Impacts of climate and land-use change on wildland fire frequency and the Amur tiger \\
\hline
\end{tabular}

biomass, which, in turn, is used to quantify the regional carbon storage and dynamics.

As mentioned above, fires cause the major disturbances in the boreal zone. Russian boreal forests have a high annual wildfire load by recent estimates up to 10 15 million ha (Conard et al., 2002). Increased wildfire activity that has been predicted in response to changing climate in this region has the potential to significantly affect Siberian forest emissions and its carbon storage capacity (Isaev et al., 2002). An integrated system of ground-air- and space-based observations of biomass burning in Russia relying on a regional fire science network has been developed within the NASA NEESPI program (PI: Ivan Csiszar, University of Maryland). Satellite-derived fire data from receiving stations in Moscow, Krasnoyarsk, Irkutsk and Khabarovsk are included in the database together with the fire products from the MODIS Land Rapid Response System (Davies et al., in press). The current focus is on the evaluation of the near-real-time fire products, generated primarily for 
management purposes. The primary products generated by the network are the locations of active fires, which are later processed into burned areas by spatial and temporal aggregation. The accuracy of the burned area estimates from aggregated hotspots is a function of spatial and temporal coverage. In particular, fire spread determines whether there are gaps between consecutive fire detections. To study this effect, fire clustering and spread rate retrieval algorithms were developed (Loboda and Csiszar, 2007-this issue). Mapping of fires is used in a related pilot project, which aims at studying biodiversity issues in the Russian Far East, specifically the threat and impact of catastrophic fires on the Amur tiger (PI: Loboda, University of Maryland). Wildland fires in Scotch pine and larch forests are studied in a project led by the US Forest Service (PI: Conard, USFS) by combining multi-scale satellite, airborne and ground measurements to support validation and extend the accuracy and capability of remote sensing to quantify and monitor the role of these fires in carbon cycling in the forests of Siberia. The goal is to develop validated estimates of fire areas, fire severity, emissions and the impact of fire on carbon balance from both medium- (MODIS) and coarseresolution (AVHRR) satellite data. This project also evaluates the potential for estimating emissions directly from satellite middle infrared channels through relationships between energy release from fire and fire emissions. The NASA NEESPI program supports an analysis of 20 years of existing NASA-derived satellite products in combination with meteorological data sets and Siberian ground-based extreme fire events data sets, to study the coincidence of severe fires and the meteorological and synoptic-scale weather characteristics that generate the conditions necessary to sustain extreme fire events (PI: Soja, National Institute of Aerospace). The ultimate goal of this project is to expand the scope of existing bioclimatic models to predict fire regimes under climate change scenarios for the forthcoming decades up to a century and to simulate changes in phytomass and in the extent and distribution of the dominant vegetation.

Northern China comprises a substantial portion of the boreal ecosystems within the NEESPI geographic domain, representing an extension of the forest ecosystem across the border with Russia. Processes in the boreal zone of northern China are similar to those in the Russian Far East. Maps of rapid LCLUC and quantification of carbon stocks and the uncertainty about the carbon cycle using existing and well validated biogeochemical models under various land-cover change scenarios in China are being developed in the NASA NEESPI program (PI: Qi, Michigan State University). The program includes studies examining the conse- quences of China's new national forest policy and economic development as they are manifested in contrasting disturbance patterns caused by fires near the border between China and Russia (PI: Sun, University of Maryland). The areas separated by a geopolitical border have very different trajectories of disturbance and recovery due to different management regimes in the forests on the two sides of the Amur River in eastern Russia and northeastern China. These forests are dominated by larch, and fire in early spring is a major factor in their disturbance and development. A major fire in spring of 1987 burned more than one million hectares of forests along both sides of the river (Salisbury, 1989). The Chinese government implemented a 10-year program to suppress forest fires and plant trees in the burnt areas. The Russian forest, on the other side, was naturally recovering from 1987 fire and experienced new fires in 1998 and 2003. Additionally, a new forest policy implemented in 1999 - the Natural Forest Conservation Program - and the rapid economic development of China have put heavy pressure on forest resources in the Russian Far East.

Thus, the NASA NEESPI program will analyze the ultimate impact of the natural and anthropogenic disturbances on forest ecosystem dynamics, vegetation diversity, and carbon uptake and storage in the boreal forest of Russia and China relying on NASA data sets, local forest inventory maps, and other statistical data sets and field samples. The field measurements and forest inventory maps provide ground truth data for mapping forest disturbance and biomass from all available satellite sensor measurements including optical moderate- (MODIS) and high-resolution (Landsat ETM+ and ASTER), and radar (SAR).

The tundra zone takes up a large portion of the NEESPI domain, and the program aims at studying climate-LCLUC interactions in this zone. The research will provide a contribution to the International Polar Year. The current research efforts are focused on the Yamal Peninsula and Novaya Zemlya, Russia, to examine how the terrain and anthropogenic factors of reindeer herding and resource development, combined with the climate variations, affect the spatial and temporal patterns of vegetation change and how those changes are in turn affecting traditional herding by indigenous people of the region (PI: Walker, University of Alaska). The Yamal Peninsula in northern Russia has been identified as a "hot spot" for both Arctic climate change and land-use change. The Yamal has undergone extensive anthropogenic disturbance and transformation of vegetation cover over the past 20 years due to gas and oil development and overgrazing by the Nenets reindeer 
herds. A combination of ground-based data, remote sensing and information on Nenets land-use activities are being used to develop vegetation-change models to predict future states of the tundra.

The water cycle processes of the boreal zone are as important as the carbon cycle. Changes in the hydrological cycle over Northern Eurasia control the fresh water transport to the World Ocean and interior lakes, which may affect the World Ocean thermohaline circulation (Peterson et al., 2002). LCLUC plays a substantial role in the hydrological changes. The NASA NEESPI LCLUC-Hydrology component of the program is directed at combining existing data and modeling resources within an integrated framework for diagnostic studies over historic and contemporary time frames, to identify the individual and combined impacts of climate and LCLUC and to identify "hot spots" of rapid hydrologic change (PI: Vorosmarty, University of New Hampshire). Identifying the separate and conjunctive impacts of factors such as climate change, LCLUC, fire, permafrost degradation, the redistribution of lakes and wetlands, and water engineering will be critical to understanding the full dimension of hydrologic change in the region, and in designing environmental monitoring systems to analyze these unfolding changes.

The ultimate goal of this program component is to develop an integrated picture of linked carbon-water cycle system in Northern Eurasia. Most carbon budget studies agree that the Northern Eurasian boreal forests represent a net sink of carbon; the tundra, on the other hand, is considered nearly in balance. A large uncertainty exists, however, concerning the contribution of methane emissions from wetlands, which are very sensitive to temperature. The climate warming should thus lead to increased influence of wetlands in carbon budget estimations. Lakes and wetlands are particularly prevalent in the northern latitudes: the Eurasian arctic drainage is a vast landmass that constitutes over $10 \%$ of the global land area. The presence of permafrost and modest relief impedes the subsurface drainage of water. To link the carbon and water cycles, a combination of highresolution radar data, in situ data, permafrost dynamics models and a hydrological model are used in the program (PI: Lettenmeier, University of Washington). Testing of the carbon and methane models is being performed via a combination of extrapolation of direct measurements, inverse modeling methods and other modeling studies.

To summarize the work on the boreal zone under the NASA NEESPI program, the following products are expected within the next 3 years: (1) comprehensive data sets of fire occurrence for the first half of this decade in Russia with a realistic accuracy statement of the pro- ducts, (2) information for developing recommendations on management of biomass, fire, and fire regimes to reduce $\mathrm{CO}_{2}$ and $\mathrm{CH}_{4}$ emissions, to enhance carbon storage and sustainable forest management, and to minimize negative impacts of fire on the global environment, and (3) a better ability to accurately monitor the spatial and temporal distribution and environmental impacts of wildfires across Siberia using remote sensing and to improve inventory of fire-induced changes in land cover caused. Also, it is expected that the NASA NEESPI modeling framework will (1) produce a continental-scale picture of variations in Global Primary Productivity and net ecosystem carbon exchange for the boreal forests in Northern Eurasia during the recent several years based on remotely sensed data from medium-resolution satellite sensor data, (2) develop an integrated picture of linked carbon-water cycle system of Northern Eurasia, and (3) establish the degree to which climate variability affects wildfire-induced land-cover change.

\subsection{Non-boreal zone projects}

The NEESPI domain includes vast areas of Northern Eurasia that are non-boreal, such as agricultural regions of Russia, Ukraine, Black and Caspian Sea regions and semi-arid/grassland regions of Central Asia, China and Mongolia. These areas have their own specifics in interactions between carbon cycle, water cycle, land use, ecosystems and climate. Changes in water resources and LCLUC, such as cropland abandonment and degradation of soils, which have altered carbon stores and fluxes from extensive areas in the region, have potentially affected the feedback to the climate system. Examples of LCLUC are desiccation of the Aral Sea and conversion of the steppe in Kazakhstan to the agricultural fields in 1950 s, resulting not only in changes in the carbon and water cycles but also in increasing amounts of land useinduced aerosols (wind-blown mineral dust). Dust lifted into the atmosphere can affect land processes by altering the surface radiation budget including photosynthetically active radiation, providing additional radiative heating of the boundary layer and by causing direct and indirect (via clouds) radiative forcing at the top of the atmosphere (Sokolik et al., 2001; IPCC, 2001). In addition to climate effects, dust intrusions pose serious health problems. The NASA LCLUC program investigates the interactions of LCLUC and dust loadings and their impact on climate of drylands in Northern Eurasia over the past 50 years by integrating satellite and ground-based data in a spatiotemporal statistical analysis and modeling (PI: Sokolik, Georgia Institute of Technology). 
More than a third of the world's mountain glaciers are located in the Northern Hemisphere. These glaciers represent the main source of water supply to Central Asian populations. Changes in climate are affecting the availability of these resources to the humans in lowlands. The water resources issues are critical for the arid and semiarid regions; therefore, an emphasis is made in the program to study the processes that are climate-related but affect humans in their sustainability and resilience facing the consequences of a warming climate and reduced water supply (PI: Aizen, University of Idaho).

LCLUC affects ground surface hydrology through agricultural or grazing practices, forest exploitation, urbanization, by altering runoff, ground water, soil erosion and water quality. The modifications of the socioeconomic situation in the region have been a primary agent of change of the land-use systems during the past century, with a new cycle of changes after the break-up of the Soviet Union. The principal mechanism of LCLUC in this part of the region during the past 15 years has been the disintegration of the institutions of centralized control over the agricultural sector. NASA high-resolution satellite sensor data enable the spatio-temporal analysis of LCLUC processes over a vast area of the nonboreal zone, which encompasses forest and agricultural lands and the semi-arid regions. These data together with bio-geophysical and econometric models will allow us to project scenarios of the future effects of LCLUC on ecosystems and human welfare.

Ukraine - a bread-basket of the former Soviet Union - comprises a significant portion of the NEESPI domain. As in Russia, forestry in Ukraine has experienced major changes since the country gained independence in 1991 and subsequently transitioned into a decentralized, market-based economy. In a multinational project, the goal is to quantify the effects of changes in temperate forests on the Black Sea regional terrestrial carbon budget (PI: Woodcock, Boston University). The team uses a well-developed carbon model with remote sensing estimates of rates and kinds of landuse change to determine the net fluxes (Houghton, 2003). In another project, large-scale interactions between carbon dynamics, land use for agriculture and forestry, and climate variability are simulated with explicit biophysical descriptions of agricultural systems within existing agro-ecosystem models at various scales (PI: Tubeillo, Columbia University). Site crop models are being used to focus on plant growth and yield dynamics as a function not only of climate, but also of genetic and management factors such as cultivar characteristics, irrigation and fertilization schedules, rotation types, and soil management. In the west, Ukrainian forests are mostly in the mountainous Carpathian region. Severe flooding and landslides in the Ukrainian Carpathians have had significant negative economic and social impacts. The relation of flooding to LCLUC is being studied to determine the extent (magnitude and frequency) to which flood susceptibility of watersheds has increased due to increased intensity and extent of forest harvesting, deforestation, and surface mining/ reclamation within the last 50 years (PI: Eshleman, University of Maryland). Hydrological models are being used to make predictions of flooding responses for a group of representative watersheds for which hydrometeorological field data are sparse or unavailable, and these predictions are used to quantitatively evaluate the impact of regional LCLUC on the flooding regime (DeFries and Eshleman, 2004; Eshleman, 2004; Negley and Eshleman, 2006). LCLUC in the Carpathian Mountains as related to biodiversity in Eastern Europe is studied in a pilot project (PI: Radeloff, University of Wisconsin). The goal is to examine how the breakdown of the Soviet Union affected LCLUC in four bordering countries in the Carpathian region and to identify the consequences for biodiversity by simulating various LCLUC scenarios. The NASA LCLUC hydrological component of the program includes investigating water quality issues in Northern Eurasia. Currently, only one project is focused on the LCLUC effects on water quality for the Dnieper and Don River Basins - two major river basins in Ukraine and Russia (PI: Gitelson, University of Nebraska). In this study, integrated assessment of surface water quality changes related to LCLUC following the collapse of the Soviet Union is undertaken with MODIS and SeaWiFS data using advanced algorithms to retrieve trophic status of turbid productive waters.

Semi-arid regions in the NEESPI geographic domain are undergoing rapid social, economic or demographic changes and there is a need for a stronger scientific underpinning to resource management. Central Asia represents a particularly important area where water resources have undergone devastating environmental alterations over the recent decades due to LCLUC (e.g., Saiko and Zonn, 2000). The program investigates the roles and consequences of changes in climate and landuse intensity on the land carbon stores and fluxes and land-atmosphere interactions in the steppes of Eurasia during the past 100 years by integrating land-use studies, remote sensing analysis, carbon biogeochemical and atmospheric modeling (PI: Ojima, Colorado State University). The water resources issues, however, are most critical for the region; their availability and proper management may have repercussions of global importance, including political disturbances and confrontations. 
One approach is to identify the regions of current and future water stress under various scenarios of LCLUC and global climate change (PI: Vorosmarty, University of New Hampshire). The use of satellite information to define accurately and objectively important components of the land-use and hydrological systems (e.g., area of irrigated land and vegetation) along with in situ data is critical for achieving the goals of the program. The program will quantify the LCLUC in Central Asia, estimating transpiration of terrestrial vegetation after changes in land cover and identifying irrigation in cropland and pastureland by combining Landsat and MODIS images to map small water bodies, most of them being likely part of irrigation infrastructure. To improve our understanding of the sustainability and vulnerability of the dry land systems and how they affect hydrologic processes, the NASA LCLUC program supports an additional project, which focuses on interaction of vegetation dynamics with such variables as evapotranspiration, surface runoff, infiltration, soil moisture, as well as with human activities aiming at classifying dry land vegetation by both dominant vegetation type and level of coverage (PI: Geerken, Yale University). Ecological changes that occurred during the past $10-15$ years are studied using available moderateand coarse-resolution data. Using model runs over the past 25 years at a spatial resolution of $1 \mathrm{~km}$ the team studies relationship between climate variables and timing of crop growth, and the impacts of past and current agricultural land use and changes. Another NASA LCLUC project explores the local and regional socioeconomic consequences of changes in water resource use and availability in the Caspian and Aral Sea basins using an inverse process approach with satellite-driven biophysical modeling to quantitatively assess water resource demand in arid regions by comparing the carbon and water flux modeled under both irrigated and non-irrigated conditions (PI: Imhoff, NASA Goddard Space Flight Center). A climate-driven agro-economic model developed by USDA is used to explore regional vulnerability to water scarcity as a function of the economic consequences of agricultural practices, water use and climate variability. In a recent study with AVHRR data, institutional changes were found to have important effects on the regional hydrometeorology of Kazakhstan (de Beurs and Henebry, 2004). Statistically significant changes in vegetation following the collapse of the Soviet Union are likely to be a result of agricultural de-intensification. The change analysis with MODIS NDVI image time series at $250 \mathrm{~m}$ resolution for 2001-2003 to evaluate the influence of abandoned agricultural lands on observed phenology confirmed the previous results with coarser resolution data. The NASA LCLUC program is supporting analysis extended to the entire Eurasian semi-arid grain belt-a globally significant food production zone (PI: Henebry, South Dakota State University). The investigation utilizes a meso-scale meteorological model linked to an appropriate land surface model and retrospective analyses of observational data, including temperature and precipitation from ground stations, image time-series from satellite microwave radiometers (SSM/I, AMSR-E), as well as surface reflectance and vegetation index data.

The drylands of the NEESPI region includes northern China. The region of Inner Mongolia is characterized by tall-to-short steppes with various degrees of land-use intensity. As a result of intensified grazing and altered hydrological cycles over the last five decades, approximately $60 \%$ of the landscape has become highly disturbed shrublands. The NASA LCLUC program supports a project on relating LCLUC to hydrological changes in dry lands of northern China (PI: Chen, University of Toledo). In this study, the team conducts analysis of current and historic land-use patterns, shifts in biome boundaries and in soil-vegetation-atmosphere water balance. This project is designed to target mechanistic feedbacks between energy-water balance and the shift from natural to agricultural and managed ecosystems, using eddy flux measurements and integrated databases in Eastern, Central, and Western Inner Mongolia.

Summarizing the non-boreal zone projects under the NASA NEESPI program, the following is expected from this research: (1) minimizing the uncertainties associated with the carbon cycle dynamics in the nonboreal region, particularly associated with land-use change, (2) advancing the development of methods for semi-automated monitoring of environmental change over large areas, (3) regional scaling of key agronomic indicators (length of growing season as a function of temperature, water balance and soil characteristics), (4) confirming whether abrupt but far-reaching institutional change affects regional hydrometeorology, and providing quantitative assessments of the vulnerability of agricultural activities in a climate characterized by high inter-annual variation, (5) providing a synopsis of rangeland resources (vegetation, soil, and water), apparent trends and triggering causes that will serve as a basis for managing grazing activities, initiating preventive measures and elaborating sustainable rehabilitation strategies, and (6) compiling existing data sets on crop and non-boreal forestry production, including major crop types and management regimes from 1990 to present. In general, it is expected that the modeling in combination with the data analysis within the NASA LCLUC non-boreal zone component will develop the 
capability to predict the effects of land-use and climate change on energy and water fluxes.

\subsection{Science data support for the NEESPI}

The NEESPI program is developing an infrastructure for providing remote sensing and in situ data and other informational support to facilitate implementation of NEESPI science projects. The Northern Eurasia Regional Information Network (NERIN) is a recently formed network, which emerged within the framework of the Global Observation of Forest and Land-Cover Dynamics (GOFC-GOLD, http://www.fao.org/gtos/ gofc-gold/net-NERIN.html). The NERIN is growing rapidly as an informal network of scientists and other professionals, institutions, local observational networks, and projects active in the region. The primary goal of the NERIN is to promote and coordinate the production and provision of Earth system observations for a wide range of user communities in Northern Eurasia and to the global Earth science community. Specifically, the NERIN provides information on data availability and accessibility to the ongoing NEESPI scientific projects. NERIN is currently assembling information about the content, quality, condition, and other characteristics of data sets available to support new research in Northern Eurasia. NERIN includes two related thematic components: fire and land cover. The NERIN has been formed in the boreal zone of Russia and is being expanded to the northern China and to the non-boreal zone.

Additionally, the NEESPI is relying on Science Support Centers that are established as part of the NEESPI data infrastructure for running the program. For climate data, these are located at the National Climatic Data Center in Ashville, NC, at the Research Institute for Hydrometorological Information, Obninsk, Russia, and at the Beijing Climate Center, China - the primary center for in situ climatological data in East Asia. For remote sensing data, two centers are established: at ScanEx, a private company in Moscow and a primary data holder of most remote sensing data available for Northern Eurasia, and in the U.S. at NASA Goddard Space Flight Center.

\section{Future directions}

LCLUC issues relevant to the International Polar Year (IPY, http://www.ipy.org/) will be one of the foci in the forthcoming 2-3 years. Coastal zone processes in the Arctic, land use and its interaction with climate change in sub-Arctic, in particular at forests-tundra margins, hydrology of sub-Arctic watersheds, carbon cycle-permafrost interactions, energy exchange in boreal ecosystems, represent some potential NEESPI contributions to IPY anticipated during 2007-2008.

Optical sensor data have been traditionally utilized for monitoring fires and assessing fire scars extent. However, in tundra regions due to persistent cloudiness and short periods of daylight during much of the year radar data prove to be very useful. Radars have the ability to get images of the Earth's surface through darkness and cloud cover with the resolution comparable to the optical sensors. The LCLUC program will foster data fusion and innovative methods to combine the use of optical and microwave sensor data in IPY projects.

The NEESPI framework is a uniquely international integrative regional program focusing on the primary global change science questions pertaining to Northern Eurasia. The current interdisciplinary projects described above lay the foundation for the integrative science needed to meet the goals of the NEESPI Science Plan. In the near term synergy between flux towers data satellite data and dynamic forest ecosystem models will provide an improved understanding of the carbon cycle and the impacts of different management practices. Agricultural studies combining hydrological models and remote sensing will provide a scientific basis for improved water resource management. Synergy between in situ measurement studies, climate, cryospheric, hydrological and biogeochemical modeling will provide an improved understanding of the impacts of large-scale changes in the extent and type of permafrost. This together with the socio-economic analysis should provide new insight in the potential changes in ecosystems and their interactions with humans. Applications of the improved scientific understanding should provide an exemplary regional test bed for the Global Earth Observation System of Systems (GEOSS), linking ground and satellite observations and the socio-economic survey data necessary to understand and model the processes of land-use change.

One of the areas where the NEESPI LCLUC will need enhancement is involvement of social scientists and use of socio-economic information and modeling. The advantages of having alliance of remote sensing expertise and physical science with socio-economic and human welfare data include predicting agricultural changes, monitoring of the impact of climatic changes on human health, and many other applications of societal benefits. The NEESPI serves as an organizational framework to build towards integrated Earth observations for an important region of the globe to meet user needs including those of decision-makers. The NEESPI 
promotes cooperation of multiple countries - partners as contributors to international scientific programs, ensuring that the shared observations and products are accessible by the world science community. Moreover, the NEESPI promotes capacity building in Earth observations based on the existing and emerging networks.

\section{Acknowledgements}

Thanks go to Principal Investigators of the NASA LCLUC Program whose materials were used in preparing this overview. Special thanks go to Drs. Olga Krankina (Oregon State University), Ivan Csiszar (University of Maryland), the NEESPI Project Scientist Dr. Pavel Groisman and the LCLUC Project Scientist Dr. Chris Justice for reviewing the paper.

\section{References}

Alig, R.J., Krankina, O.N., Yost, A., Kuzminykh, J., in press. Forest carbon dynamics in the Pacific Northwest (USA) and the St. Petersburg region of Russia: comparisons and policy implications. Climatic Change.

Bergen, K.L., Conard, S.G., Houghton, R.A., Kasischke, E.S., Kharuk, V.I., Krankina, O.N., Ranson, K.J., Shugart, H.H., Sukhinin, A.I., Tryfeld, R.F., 2003. NASA and Russian scientists observe landcover and land-use change and carbon in Russian forests. Journal of Forestry 101 (3), 34-41.

Conard, S.G., Sukhinin, A.I., Stocks, B.J., Cahoon, D.R., Davidenko, E.P., Ivanova, G.A., 2002. Determining effects of area burned and fire severity on carbon cycling and emissions in Siberia. Climatic Change 55, 197-211.

Davies, D.K., Santhana Vannan, S.K., Frost, P.E., Vosloo, H., Descloitres, J., Schmaltz, J., Musinsky, J., Justice, C.O., in press. Integrating Remote Sensing and WebGIS technologies to improve the delivery of global MODIS active fire data for fire management and decision support. International Journal of Applied Earth Observation and Geoinformation.

de Beurs, K.M., Henebry, G.M., 2004. Land surface phenology, climatic variation and institutional change: analyzing agricultural land cover change in Kazakhstan. Remote Sensing of Environment 89, 497-509.

DeFries, R., Eshleman, K.N., 2004. Land-use change and hydrologic processes: a major focus for the future, invited commentary. Hydrological Processes 18, 2183-2186.

Eshleman, K.N., 2004. Hydrological consequences of land use change: a review of the state-of-science. In: Defries, R., Asner, G., Houghton, S. (Eds.), Ecosystems and Land Use Change. Geophysical Monograph Series, vol. 153. American Geophysical Union, Washington, DC, pp. 13-29.

EWG, 1999. Boreal forest study: boreal forest characterization and sustainability study-Report on phase I and II results (Report Number 29100-1-T). U.S.-Russian Joint Commission on Economic and Technological Cooperation Environmental Working Group.

Gutman, G., Justice, C.O., Sheffner, E., Loveland, T., 2004. The NASA land cover and land use change program. In: Gutman, G., Janetos, A.C., Justice, C.O., et al. (Eds.), Land Change Science:
Observing, Monitoring and Understanding Trajectories of Change on the Earth's Surface. Kluwer Press.

Healey, S.P., Cohen, W.B., Zhiqiang, Y., Krankina, O., 2005. Comparison of tasseled cap-based Landsat data structures for use in forest disturbance detection. Remote Sensing of Environment 97, 301-310.

Houghton, R.A., 2003. Revised estimates of the annual net flux of carbon to the atmosphere from changes in land use and land management 1850-2000. Tellus 55B, 378-390.

Houghton, R.A., Butman, D., Bunn, A., Krankina, O.N., Schlesinger, P., Stone, T.A., in preparation. Mapping Russian forest biomass with satellites and forest inventories.

IPCC (Intergovernmental Panel on Climate Change), 2001. In: Houghton, J.T., et al. (Ed.), The Scientific Basis, Contribution of Working Group I to the Third Assessment Report of the Intergovernmental Panel on Climate Change. Cambridge Univ. Press, New York. 881 pp.

Isaev, A.S., Korovin, G.N., Bartalev, S.A., Ershov, D.V., Janetos, A., Kasischke, E.S., Shugart, H.H., French, N.H.F., Orlick, B.E., Murphy, T.L., 2002. Using remote sensing to assess Russian forest fire emission. Climatic Change 55, 235-249.

Ito, A., Penner, J.E., 2004. Global estimates of biomass burning emissions based on satellite imagery for the year 2000. Journal of Geophysical Research 109, D14S05. doi:10.1029/2003JD004423.

Kasischke, E.S., Bergen, K., Fennimore, R., Sotelo, F., Sephens, G., Janetos, A., Shugart, H.H., 1999. Satellite Imagery gives clear picture of Russia's boreal forest fires. EOS Transactions, American Geophysical Union 80, 141-147.

Krankina, O.N., Fiorella, M., Cohen, W.B., Treyfeld, R.F., 1998. The use of Russian forest inventory data for carbon budgeting and for developing carbon offset strategies. World Resource Review 10 (1), 52-66.

Krankina, O.N., Harmon, M.E., Cohen, W.B., Oetter, D.R., Zyrina, O., Duane, M.V., 2004a. Carbon stores, sinks, and sources in forests of northwestern Russia: can we reconcile forest inventories with remote sensing results? Climatic Change 67 (2-3), 257-272.

Krankina, O.N., Bergen, K.M., Sun, G., Shugart, H.H., Kharuk, V., Kasischke, E., Bergen, K.M., Masek, J.G., Cohen, W.B., Oetter, D.R., Duane, M.V., 2004b. Northern Eurasia: remote sensing of boreal forest in selected regions. In: Gutman, G., Janetos, A.C., Justice, C.O., Moran, E.F., Mustard, J.F., Rindfuss, R.R., Skole, D., Turner II, B.L., Cochrane, M.A. (Eds.), Land Change Science: Observing, Monitoring, and Understanding Trajectories of Change on the Earth's Surface. Kluwer Academic Publishers, The Netherlands, pp. 123-138.

Krankina, O.N., Harmon, M.E., Cohen, W.B., Oetter, D.R., Zyrina, O., Duane, M.V., in press. Carbon stores, sinks, and sources in forests of Northwestern Russia: can we reconcile forest inventories with remote sensing results? Climatic Change.

Loboda, T.V., Csiszar, I.A., 2007. Reconstruction of fire spread within wildland fire events in Northern Eurasia from the MODIS active fire product. Global and Planetary Change 56, 258-273 (this issue). doi:10.1016/j.gloplacha.2006.07.015.

Negley, T.L., Eshleman, K.N., in press. Comparison of stormflow responses of surface-mined and forested watersheds in the Appalachians Mountains, USA. Hydrological Processes.

Peterson, B.J., Holmes, R.M., McClelland, J.W., Vorosmarty, C.J., Lammers, R.B., Shiklomanov, A.I., Shiklomanov, I.A., Rahmstorf, S., 2002. Increasing river discharge to the Arctic Ocean. Science 298, 2172-2173.

Saiko, T.A., Zonn, I.S., 2000. Irrigation expansion and dynamics of desertification in the circum-Aral region of Central Asia. Applied Geography 20, 349-367. 
Salisbury, H.E., 1989. The Great Black Dragon Fire: A Chinese Inferno. Little Brown and Company.

Shvidenko, A., Nilsson, S., et al., 1996. Forest management and the global carbon cycle: carbon budget of the Russian boreal forest: as systems analysis approach to uncertainty. In: Kapps, M.J., Price, D.T. (Eds.), Forest Ecosystems, Forest Management and the Global Carbon Cycle. Springer-Verlag, Berlin, pp. 142-162.

Shugart, H.H., Clark, D.F., Hill, A.J., 2000. Ecological models of the dynamics of boreal landscapes. In: Kaisischke, E., Stocks, B. (Eds.), Fire in Boreal Forests. Springer Verlag, New York, pp. 389-405.

Soja, A.J., Sukhinin, A.I., Cahoon Jr., D.R., Shugart, H.H., Stackhouse Jr., P.W., 2004a. AVHRR-derived fire frequency, distribution and area burned in Siberia. International Journal of Remote Sensing 25, 1939-1960.
Soja, A.J., Cofer, W.R., Shugart, H.H., McRae, D.J., Sukhinin, A.I., Stackhouse Jr., P.W., Conard, S.G., 2004b. Estimating fire emissions and disparities in boreal Siberia (1998 through 2002). Journal of Geophysical Research 109, D14S06. doi:10.1029/204d004570, 2004.

Sokolik, I.N., Winker, D., Bergametti, G., Gillette, D., Carmichael, G., Kaufman, Y., Gomes, L., Schuetz, L., Penner, J., 2001. Introduction to special section on mineral dust: outstanding problems in quantifying the radiative impact of mineral dust. Journal of Geophysical Research 106 (18), 18015-18028.

Yan, X., Shugart, H.H., 2005. A forest gap model to simulate dynamics and patterns of Eastern Eurasian forests. Journal of Biogeography $32,1641-1658$. 